\title{
Oligodendrocyte Apoptosis Mediated by Caspase Activation
}

\author{
Chenghua Gu, ${ }^{2}$ Patrizia Casaccia-Bonnefil,, ${ }^{1}$ Anu Srinivasan,, ${ }^{3}$ and Moses V. Chao ${ }^{1}$ \\ ${ }^{1}$ Molecular Neurobiology Program, Skirball Institute of Biomolecular Medicine, New York University School of Medicine, \\ New York, New York 10016, ${ }^{2}$ Cell Biology Program, Weill Graduate School of Cornell University Medical College, New \\ York, New York 10021, and 3IDUN Pharmaceuticals Inc., La Jolla, California 92037
}

Treatment with NGF causes long-term cultures of oligodendrocytes to die via a yet undefined mechanism mediated by the p75 neurotrophin receptor. The p75 receptor belongs to the TNF receptor superfamily of molecules, which includes Fas and p55 TNF receptors. The Fas and TNF receptors use adaptor molecules to recruit and activate caspase- 8 to the receptor. Using a combination of immunohistochemical and Western blotting assays, we have examined caspase activity during NGF-induced apoptosis. Interestingly, although caspase- 1 [interleukin- $1 \beta$-converting enzyme (ICE)], caspase-2, caspase- 3 , and caspase- 8 were expressed in oligodendrocytes, only caspase-1, -2 , and -3 were activated after NGF treatment, whereas caspase- 8 was not. These data suggest that the mechanism of apoptosis by NGF through the p75 receptor is different from TNF and Fas-mediated killing. $\gamma$ Radiation of oligodendrocytes also activated a similar subset of caspases as NGF, indicating that NGF-induced oligodendrocyte apoptosis uses a similar cell death execution mechanism as injury models. This consolidates a potential role of the p75 neurotrophin receptor during stress and inflammatory conditions.

Key words: apoptosis; p75 neurotrophin receptor; NGF; caspase; TNF; Fas; oligodendrocyte
In addition to myelinating multiple axons in the CNS, oligodendrocytes possess a number of critical properties, such as the ability to provide trophic support and regulate regeneration after nerve injury. As such, the number of oligodendrocyte cells generated during development must be under careful regulation. Considerable oligodendrocyte cell death occurs during development (Barres et al., 1992) and also after traumatic conditions, when oligodendroglial cells become more sensitive to cytokines that are released at the site of injury. The sensitivity of oligodendrocytes is illustrated by the effects of TNF- $\alpha$, which can cause cytotoxicity at concentrations that do not affect other cell types, such as astrocytes or neuronal populations (Selmaj and Raine, 1988). Apoptosis induced by increased ceramide levels also indicated that oligodendrocytes are much more susceptible to cell death induced by specific stimuli than astrocytes and neuronal cells (Casaccia-Bonnefil et al., 1996a).

We have reported that NGF can induce apoptosis of terminally differentiated oligodendrocytes after long-term culture (Casaccia-Bonnefil et al., 1996b). Several examples of p75mediated cell death now exist (Rabizadeh et al., 1993; Barrett and Bartlett, 1994; Frade et al., 1996; Bamji et al., 1998), however, the cellular and molecular basis for this activity is not understood. The cytoplasmic portion of the p75 receptor contains a death domain sequence that resembles the Fas and TNF receptor death domain (Liepinsh et al., 1997). The death domain has been shown to contribute to apoptotic signaling by TNF and the Fas ligand (Nagata, 1997). Oligomerization of the receptors via these do-

\footnotetext{
Received Nov. 23, 1998; revised Feb. 5, 1999; accepted Feb. 5, 1999.

This work was supported by grants from the National Institutes of Health (M.V.C.) and the Multiple Sclerosis Society (P.C.B.). We thank Christina Tu for technical advice.

Correspondence should be addressed to Moses V. Chao, Skirball Institute, New York University School of Medicine, 540 First Avenue, New York, NY 10016. Copyright (C) 1999 Society for Neuroscience $0270-6474 / 99 / 193043-07 \$ 05.00 / 0$
}

mains provides anchorage for adaptor molecules to activate the cell death execution machinery.

Programmed cell death requires activation of cysteine protease enzymes that possess the ability to cleave after an aspartyl residue (Ellis et al., 1991; Alnemri et al., 1996). This family of proteases, which now number 14 caspases (cysteine aspartyl proteases), shares similarities to ced-3, an essential cell death gene in Caenorhabditis elegans. The caspases have been divided into two main groups, initiator enzymes (caspase-1, -2, -8, and -9) and effector caspases, such as caspase-3. Whereas caspase-9 is required during brain development (Hakem et al., 1998; Kuida et al., 1998), other enzymes, such as caspase-1, are involved during inflammatory conditions.

Caspases are all expressed as proenzymes that contain three domains, the N-terminal domain, the large subunit of $\sim 20 \mathrm{kDa}$ (p20), and a small subunit of $\sim 10 \mathrm{kDa}(\mathrm{p} 10)$. After activation, the proenzyme is cleaved at the consensus sites into p20 and p10 subunits and forms a catalytic tetramer (Thornberry and Lazebnik, 1998).

In the present study, we address the identity of the cell death execution machinery during p75-mediated apoptosis. Despite much current interest in this topic (Carter and Lewin, 1997; Dechant and Barde, 1997; Barker, 1998; Bredesen et al., 1998; Casaccia-Bonnefil et al., 1998; Frade and Barde, 1998), the cell death mechanisms initiated by the p75 neurotrophin receptor have not been well defined. Here, we report that cultured oligodendrocytes express several caspase family members, including caspase-1 [interleukin- $1 \beta$-converting enzyme (ICE)], caspase-2 (Nedd-2), caspase-3 (CPP32/Yama), and caspase-8. Caspase-8 activation by Fas ligand or TNF has been linked by recruitment of the adaptor molecule FADD (FAS-associated death domain) to the receptor complex (Nagata, 1997). Interestingly, p75 receptor, a member of the same TNF superfamily, does not activate caspase-8, suggesting that a different set of caspases is involved in the execution of oligodendrocyte cell death induced by the p75 
NGF receptor. In contrast, caspase-1 is strongly activated by NGF and other injury stimuli, further supporting the association of specific caspases with inflammatory conditions.

\section{MATERIALS AND METHODS}

Cell culture. Mixed glial cultures were prepared from neonatal Sprague Dawley rat cortex. After plating on poly-D-lysine-coated $75 \mathrm{~cm}^{2}$ flasks, cultures were grown at $37^{\circ} \mathrm{C}$ in a humidified incubator with $5 \% \mathrm{CO}_{2}$ for $7 \mathrm{~d}$, replacing the medium every $3 \mathrm{~d}$. Macrophages and loosely attached cells were then removed from the astrocyte monolayer by shaking cultures at $425 \mathrm{rpm}$ for $10 \mathrm{~min}$ (McCarthy and de Vellis, 1980). After two washes in PBS, cells were fed and placed in the incubator for at least $3 \mathrm{hr}$. Oligodendrocytic precursors were separated from the astrocyte monolayer by shaking overnight at $250 \mathrm{rpm}$ on a rotary shaker. Oligodendrocyte cultures were typically grown for $24 \mathrm{hr}$ in NM15 media (MEM containing $15 \%$ FCS, $6 \mathrm{mg} / \mathrm{ml}$ glucose, $10 \mathrm{U} / \mathrm{ml}$ penicillin, and $10 \mathrm{mg} / \mathrm{ml}$ streptomycin) after preplating and then switched to oligodendrocyte differentiation media as described previously (Casaccia-Bonnefil et al., 1996b; Yoon et al., 1998) to serum-free medium consisting of BME: Ham's F-12 (1:1 v/v) supplemented with $6 \mathrm{mg} / \mathrm{ml}$ D-glucose, $100 \mathrm{U} / \mathrm{ml}$ penicillin, $100 \mu \mathrm{g} / \mathrm{ml}$ streptomycin, $100 \mu \mathrm{g} / \mathrm{ml}$ transferrin, $25 \mu \mathrm{g} / \mathrm{ml}$ insulin, $20 \mathrm{~nm}$ progesterone, $60 \mu \mathrm{M}$ putrescine, $30 \mathrm{~nm}$ selenium, $6.6 \mathrm{~mm}$ glutamine, and $0.5 \mu \mathrm{M}$ thyroxine.

For cell death assays, oligodendrocyte cultures were grown for $7 \mathrm{~d}$ and treated with NGF at $100 \mathrm{ng} / \mathrm{ml}$. For the treatment with caspase inhibitors, cells were pretreated with the appropriate dilutions of the drugs or DMSO for $30 \mathrm{~min}$ before NGF exposure. Acetyl-tyrosyl-valyl-analylaspart-1-aldehyde (YVAD-CHO) and acetyl-aspartyl-glutamyl-valylaspart-1-aldehyde (DEVD-CHO) were prepared in DMSO according to the manufacturer's instructions (Peptides International, Louisville, KY).

For irradiation, cultures were treated with $3200 \mathrm{rads}$ (100 rads/min for $32 \mathrm{~min}$ ) and then harvested for cell lysates either 3 or $6 \mathrm{hr}$ later.

Antibody staining for differentiated oligodendrocytes. The $\mathrm{O} 1$ mouse monoclonal antibody (a generous gift from Drs. Steven Pfeiffer and Rashmi Bansal at University of Connecticut Health Center, Farmington, CT) was used to identify oligodendrocytes. Cells were gently washed three times with PBS and incubated alive with $\mathrm{O} 1$ antibody at 1:100 dilution in antibody buffer (3\% BSA and 3\% fetal calf serum in HBSS buffer) for $30 \mathrm{~min}$ at room temperature. For double staining, cells were then fixed and processed for either terminal deoxynucleotidyl transferase-mediated biotinylated UTP nick end labeling (TUNEL) or CM1 staining as described below. Finally, cells were incubated with O1 secondary antibody and Texas red conjugated goat anti-mouse $\operatorname{IgM}$ antibody (Jackson ImmunoResearch, West Grove, PA) at 1:100 dilution in PBS for $30 \mathrm{~min}$ at room temperature.

TUNEL assay. In situ detection of apoptotic cells was performed by using a TUNEL method. After incubation with $\mathrm{O} 1$ antibody, cells were fixed with $4 \%$ paraformaldyhyde for $30 \mathrm{~min}$ at room temperature and permeabilized with $0.1 \%$ Triton X-100 and $0.1 \%$ sodium citrate for $2 \mathrm{~min}$ on ice. After several rinses, samples were processed for TUNEL using the in situ cell death detection assay following the manufacturer's instructions (Boehringer Mannheim, Indianapolis, IN). Double-stained cells were visualized by fluorescence microscopy. Apoptotic cells were determined by counting the percentage of TUNEL-positive (TUNEL +) cells among O1-positive $(\mathrm{O} 1+)$ cells in three fields across the coverslip. At least 400 cells were counted for each condition.

Caspase- 3 staining. The polyclonal CM1 antibody specific for the p18 subunit of cleaved caspase- 3 was made against a p18 C-terminal peptide of human CPP32 and was affinity purified (Srinivasan et al., 1998b). After fixation with $4 \%$ paraformaldehyde, the cells were incubated with blocking buffer ( $10 \%$ normal goat serum and $0.4 \%$ Triton X-100 in $1 \times$ PBS) for 1-2 hr at room temperature. Primary antibody CM1 was used at 1:1000 dilution in antibody incubation buffer ( $2 \%$ normal goat serum and $0.4 \%$ Triton X-100 in $1 \times$ PBS) for $1-2 \mathrm{hr}$ at room temperature. Cells were then gently washed three to four times with $1 \times$ PBS $-0.1 \%$ Tween 20 , followed by incubation with biotinylated secondary antibody for $1 \mathrm{hr}$ at room temperature (Vector Laboratories, Burlingame, CA) at a 1:500 dilution in antibody incubation buffer. Cells were visualized using Fluorescein-conjugated Avidin DCS (Vector Laboratories) at 1:250 for $30 \mathrm{~min}$. Double immunoreactivity was analyzed by confocal microscopy using a Leica (Nussloch, Germany) TCS confocal microscope.

Immunoblotting. Cells were lysed in radio-immuno-protein assay buffer (150 mm NaCl, $1 \%$ NP-40, 0.5\% deoxycholate, $0.1 \%$ SDS, $50 \mathrm{~mm}$ Tris, $\mathrm{pH} 8.0,2 \mathrm{mg} / \mathrm{ml}$ aprotinin, $1 \mathrm{mg} / \mathrm{ml}$ leupeptin, and $25 \mu \mathrm{g} / \mathrm{ml}$ phenylmeth- ylsulfonyl fluoride) for $15 \mathrm{~min}$ at $4^{\circ} \mathrm{C}$ and centrifuged at $14,000 \mathrm{rpm}$ for $15 \mathrm{~min}$ at $4^{\circ} \mathrm{C}$, and the supernatant was collected as the whole-cell lysate. Protein concentration was estimated by the Bio-Rad Protein Assay using BSA as the standard. Cell lysates $(50 \mu \mathrm{g})$ were run on 12 or $15 \%$ SDS-PAGE gels and transferred to Immobilon-P membrane (Millipore, Bedford, MA). After blocking nonspecific membrane binding with $1 \times$ Tris-buffered saline-Tween 20 (TBST) containing 5\% milk for $1 \mathrm{hr}$, membranes were incubated for $1 \mathrm{hr}$ in primary antibody [anti-caspase-3 polyclonal antibody (CSP-3); IDUN Pharmaceuticals, La Jolla, CA] at 1:1000 dilution, anti-caspase 8 polyclonal antibody (CSP-8; Idun Pharmaceuticals) at 1:1000 dilution, anti-ICE/p10(M-20) (Santa Cruz Biotechnology, Santa Cruz, CA) at 1:500 dilution, anti-Nedd-2/p12(C-20) (Santa Cruz Biotechnologies) at 1:500 dilution, or anti-actin monoclonal antibody (Sigma, St. Louis, MO) at 1:5000 dilution. The blots were washed three times with TBST buffer and then incubated with horseradish peroxidase-conjugated anti-rabbit (1:5000 dilution) or anti-mouse (1:10000 dilution) secondary antibody (Boehringer Mannheim). Immunoreactive bands were visualized by chemiluminescence using Supersignal (Pierce, Rockford, IL) and exposed to x-ray film. The gels were scanned and quantitated by Image Quant V1.1 (Molecular Dynamics, Sunnyvale, CA). The levels of caspases and actin were quantitated by the Image Quant program, and the relative amount of caspases in each lane was obtained after normalization with the $\beta$-actin values in the same lane.

\section{RESULTS \\ NGF-induced apoptotic death can be prevented by caspase inhibitors}

Site-specific tetrapeptide protease inhibitors have been developed to block caspase proteolytic activity (Nicholson, 1996). These inhibitors were designed based on the optimal recognition sequence of a given caspase substrate. For caspase-1 (ICE), YVAD is the preferred substrate, whereas DEVD is preferred for caspase-3 or CPP32 (Enari et al., 1996). Caspase-3 is involved in neuronal death during brain development (Kuida et al., 1996) and in apoptosis induced by withdrawal of trophic support, $\mathrm{K}^{+} \mathrm{de}-$ privation, and glutamate excitotocity in neuronal cultures (Milligan et al., 1995; Schulz et al., 1996; Eldadah et al., 1997; Hara et al., 1997; Namura et al., 1998). To address caspase involvement in NGF-induced cell death through its p75 receptor in cultured oligodendrocytes, we tested whether caspase-3-like and caspase1-like inhibitors, DEVD-CHO and YVAD-CHO, would prevent the apoptotic response.

We have reported previously NGF-dependent cell death in cortical oligodendrocytes isolated from postnatal rat brain (Casaccia-Bonnefil et al., 1996b). To characterize this process, confocal microscopy was used to follow apoptosis. Oligodendrocytes were identified using the monoclonal antibody $\mathrm{O} 1$ directed against the glycolipid galactocerebroside, a major component of the myelin bilayer (Mirsky et al., 1980; Stoffel and Bosio, 1997). As shown in Figure $1 A$, $\mathrm{O} 1$ immunoreactivity can be seen not only in the cell body and processes but also in the myelin sheets that are extended by fully differentiated oligodendrocytes (Bansal et al., 1989).

After NGF treatment for $4 \mathrm{hr}$, nuclear TUNEL-positive staining and disintegration of cellular processes in an O1-positive cell could be observed (Fig. $1 B$ ). Pretreatment with the caspase inhibitors DEVD-CHO and YVAD-CHO prevented both nuclear DNA fragmentation, as evidenced by the lack of TUNEL staining, and disintegration of cellular processes (Fig. 1). Quantitation of TUNEL+ O1 + cells revealed $45 \%$ oligodendrocyte cell death in NGF-treated cultures after $4 \mathrm{hr}$, which was reduced to background levels ( $10 \%$ or less) if cells were pretreated with either DVED-CHO or YVAD-CHO (Fig. 2). Control cultures receiving DEVD-CHO or YVAD-CHO alone did not show any alterations in cellular viability (Figs. 1,2). Caspase inhibitors there- 

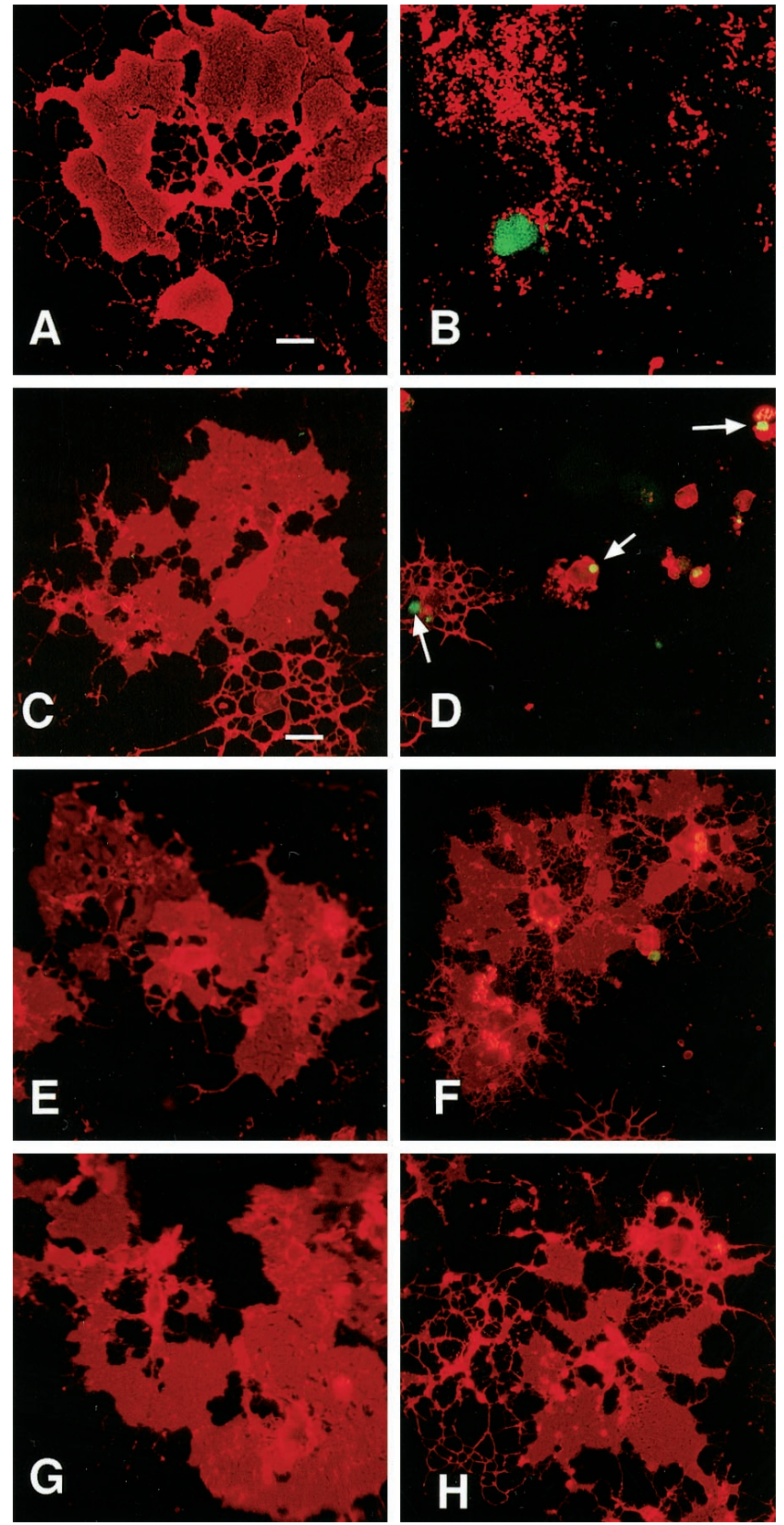

Figure 1. NGF-induced apoptosis of mature oligodendrocytes is blocked by the caspase inhibitors YVAD-CHO and DEVD-CHO. Confocal microscopy of untreated $(A)$ or NGF-treated $(B)$ oligodendrocyte cultures immunostained with antibodies against the specific oligodendrocyte marker O1 (red) and TUNEL (green) are shown. Immunofluorescence microscopy of cultures treated with $100 \mu \mathrm{M}$ DMSO $(C)$, YVAD-CHO $(E)$, or DEVD-CHO $(G)$ in the absence of NGF $(C, E, G)$ or the presence of $100 \mathrm{ng} / \mathrm{ml} \mathrm{NGF}$ for $4 \mathrm{hr}(D, F, H)$. The arrows in $D$ indicate TUNEL-positive nuclei in NGF-DMSO-treated cultures. Scale bar: $A, B$, $10 \mu \mathrm{m} ; C-H, 25 \mu \mathrm{m}$.

fore prevent NGF-induced oligodendrocyte apoptosis, suggesting p75 signaling involves downstream activation of caspases.

\section{Selective activation of caspases}

One measure of caspase activation is proteolytic cleavage of the precursor form, or procaspase, into specific smaller size products (Nicholson, 1996). For this reason, cell lysates from oligodendrocyte cultures treated with NGF were processed for Western blot

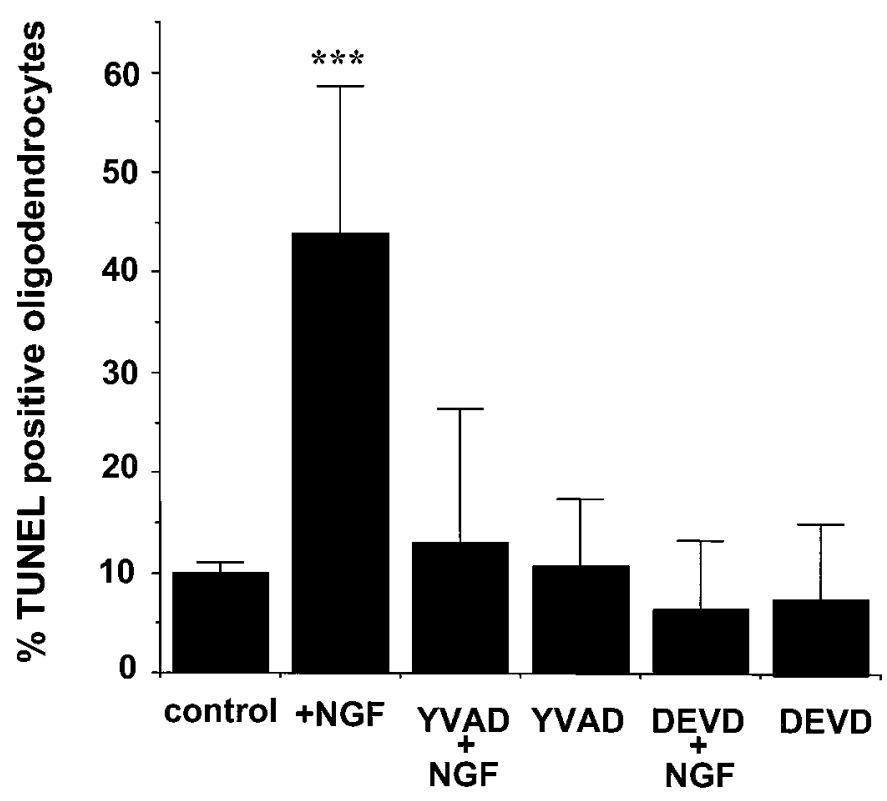

Figure 2. Quantification of apoptotic oligodendrocytes in the presence of the caspase inhibitors. Bar graphs indicate O1-TUNEL doublepositive-stained cells in each treatment expressed as percentage of total O1-positive cells. Cells were counted in at least three separate fields across the large diameter of each coverslip. The results represent the mean \pm SEM of the cells from nine separate determinations. Asterisks indicate that the percentage of TUNEL-positive oligodendrocytes in the NGF treatment is statistically significant when compared with the remaining treatments; two-tailed $t$ test; $p<0.01$.

analysis using specific polyclonal antibodies that recognize the proform and cleavage products of the individual caspases, such as ICE, Nedd2, CPP32 (caspases 1-3), and Flice/Mach (caspase-8). All four of the proenzymes were expressed in primary cortical oligodendrocytes under the described culture conditions. However, only specific caspase members were proteolytically processed after NGF treatment.

Interestingly, caspase-8, which has been shown to be required for TNF and Fas receptor apoptotic signaling, was not activated in NGF-treated oligodendrocytes (Fig. $3 A$ ). This was demonstrated by immunoblot analysis of oligodendrocytes undergoing cell death by NGF using a caspase-8-specific antibody generated against the recombinant caspase- 8 (Srinivasan et al., 1998a). To test the ability of caspase- 8 to be cleaved in mature oligodendrocytes, a different apoptotic stimulus, staurosporine, was used as a control. Staurosporine is a protein kinase inhibitor and acts as a strong death inducer on many mammalian cell types, including oligodendrocytes (Jacobson et al., 1997). After staurosporine treatment, caspase- 8 was cleaved into a p20 final cleavage product and several intermediate forms (Fig. 4), indicating that sequential caspase- 8 processing can occur in oligodendrocytes. The absence of caspase- 8 cleavage products in NGF-treated oligodendrocyte cultures indicates that caspase-8, or Flice/Mach, is not involved in NGF-induced oligodendrocyte death, and therefore p75 signaling differs from Fas or TNF receptor action.

Caspase-1 or ICE was the first identified member of mammalian caspases (Yuan et al., 1993). Analysis of caspase-1-deficient mice suggested that ICE was not involved in apoptosis during normal development (Li et al., 1995) but represents an important component of the machinery that induces apoptosis during inflammatory conditions (Fantuzzi and Dinarello, 1996; Li et al., 


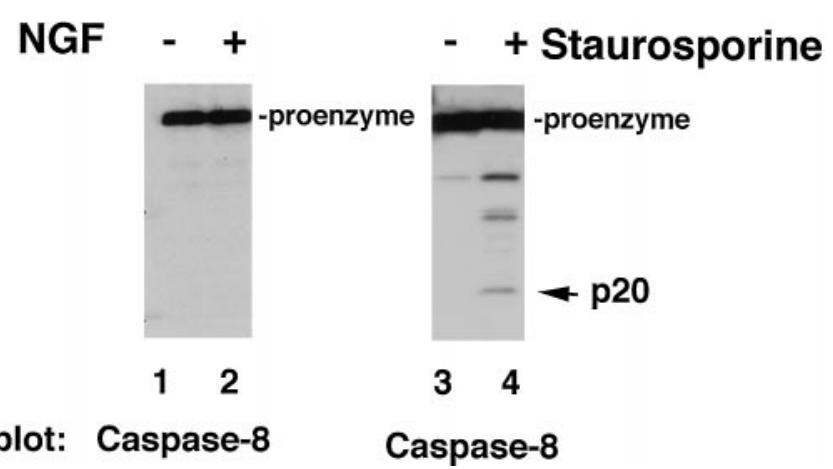

Figure 3. Caspase-8 activation in cultured oligodendrocytes after distinct apoptotic stimuli. Western blot analysis with anti-caspase- 8 polyclonal antibody of cultures treated with either $100 \mathrm{ng} / \mathrm{ml} \mathrm{NGF}(A)$ or $1 \mu \mathrm{M}$ staurosporine $(B)$. $A$, Total cell lysates $(50 \mu \mathrm{g})$ from untreated oligodendrocytes cultures (lane 1) or after $4 \mathrm{hr}$ of NGF treatment (lane 2) were processed for caspase- 8 expression and processing. $B$, Total cell lysates $(30 \mu \mathrm{g})$ from untreated oligodendrocyte cultures (lane 3) or cultures treated for $4 \mathrm{hr}$ with $1 \mu \mathrm{M}$ staurosporine (lane 4 ) were assessed. The procaspase and the processed forms are indicated.
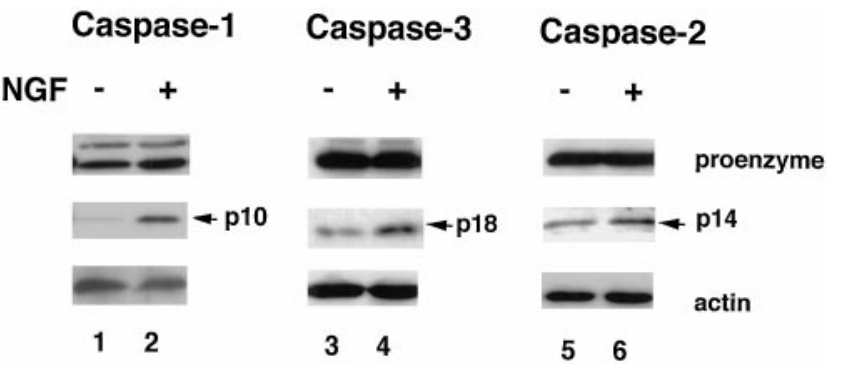

Figure 4. Caspase-1, -2, and -3 are processed in NGF-treated cultured oligodendrocytes. Total cell lysates $(50 \mu \mathrm{g})$ from either untreated oligodendrocyte cultures (lanes 1, 3,5) or NGF-treated cultures (lanes 2, 4, 6) were loaded on a $15 \%$ SDS-PAGE gel, Western blotted with anticaspase-1 antibody ICEp10(M-20) (lanes 1, 2), anti-caspase-3 antibody CSP-3 (lanes 3, 4), or anti-caspase-2 antibody Nedd-2p12 (lanes 5, 6). The top panels indicate the procaspase forms indicated as proenzyme. The middle panels are the processed forms (p10 or p20 subunit) of the caspases, indicated by the arrows. The bottom panels are internal controls for $\alpha$-actin levels.

1997). More recently, caspase-1 has been shown to be activated after ischemia (Hara et al., 1997). NGF treatment of differentiated oligodendrocytes resulted in processing of the $45 \mathrm{kDa}$ proform to its intermediate forms and final active product p10 (Fig. 4 , lanes 1,2$)$. The antibody against the $\mathrm{p} 10$ subunit was made to a peptide sequence at the $\mathrm{C}$ terminus of caspase- 1 (amino acids 382-401) and was shown to be specific for caspase-1 (Bhat et al., 1996; Shimizu et al., 1996). The faint cleavage products in the control lane are consistent with the background level of death observed in $7 \mathrm{~d}$ in vitro cultures. NGF significantly increased the processed products of caspase-1 eightfold over untreated cultures. This result indicates that caspase- 1 is preferentially activated during NGF-induced oligodendrocyte apoptosis.

Caspase-2 (Nedd-2) is another upstream initiator of proteolytic cascades (Thornberry and Lazebnik, 1998) that can be activated after trophic factor deprivation of PC12 cells (Troy et al., 1997) and dexamethasone-induced thymocytes apoptosis (Hakem et al., 1998). Also in this case, using a specific Nedd-2 affinity-purified antibody (Srinivasan et al., 1996) against the C-terminal region of mouse caspase-2 (amino acids 432-451), both the proform and the p14 form (Fig. 4) were detected. NGF treatment resulted in
3.5 -fold increase of the p14 cleavage product. Equal amount of protein loading was confirmed by anti-actin immunoblotting (Fig. 4). Also in this case, the basal level of p14 observed in the control cultures reflected the normal background level of death observed in $7 \mathrm{~d}$ in vitro cultures.

Caspase-3 is a critical downstream effector of the cell death process, and its activation has been detected in many apoptotic events (Thornberry and Lazebnik, 1998). It is synthesized as a 32 $\mathrm{kDa}$ proform, which is cleaved during activation into a large form of $18 \mathrm{kDa}$ based on the apoptotic signal and a smaller $12 \mathrm{kDa}$ subunit (Namura et al., 1998). Using an antibody generated against the fully processed caspase- 3 protein, which has been shown to be specific for both proform and cleavage products (Srinivasan et al., 1998b), we detected the $32 \mathrm{kDa}$ proform in both NGF-treated and untreated cultures. However, NGF treatment resulted in a sixfold increase of the p18 product (Fig. 4), as evaluated by densitometric analysis (Image Quant program). The basal level of the p18 protein reflected the normal background level of death observed in $7 \mathrm{~d}$ in vitro cultures. Western blotting with anti-actin antibody was used as a control for equal amount of protein loading. These results indicated that caspase- 2 and caspase-3 are also activated during NGF-induced oligodendrocyte death.

\section{In situ detection of the active form of caspase-3}

To provide more detailed information about cellular localization of the activated form of the caspase in the oligodendrocyte primary culture, we used immunocytochemical analysis of NGFtreated cultures using a newly characterized CM1 antibody recognizing only the active product of the p18 subunit of caspase-3. The CM1 was generated against the C-terminal propeptide of CPP32 and was affinity purified. The antibody selectively recognizes the p18 kDa cleavage product, not the inactive proform of caspase-3, and was used previously to detect activated caspase-3 in a variety of model systems (Kuida et al., 1996; Cecconi et al., 1998; Namura et al., 1998; Srinivasan et al., 1998b) Double immunofluorescence was used to detect the presence of the p18 subunit of caspase-3 in oligodendrocytes labeled with the marker O1. Localization of the p18 subunit of CPP32 was observed in NGF-treated oligodendrocytes but not untreated cultures (Fig. 5). After 4 and $8 \mathrm{hr}$ of NGF treatment, the p18 subunit of caspase-3 was detected in the oligodendrocyte cell body (Fig. $5 B, C)$. Previous experiments with the CM1 antibody indicated that the enzyme could be localized in the cytoplasm and nucleus (Kuida et al., 1998; Namura et al., 1998). This result further consolidates the role of caspase-3 activation in the oligodendrocyte cell death after NGF treatment.

\section{Radiation damage}

To determine whether the proteolytic cascade activated by NGF in oligodendroctyes also occurred in other injury conditions, we evaluated the consequences of $\gamma$ Irradiation of oligodendrocyte cultures. Oligodendrocyte cells are sensitive to $\gamma$ radiation and undergo apoptosis in the adult spinal cord (Li et al., 1996). The activation of procaspase processing in response to ionizing radiation was assessed by Western blot analysis. Twenty-four hours after radiation, oligodendrocytes undergo cell death as measured by an increase in the high-density lipoprotein level from 20 to $45 \%$. Three and $6 \mathrm{hr}$ after irradiation, the cleavage products of caspase- 1 and caspase- 3 were significantly increased compared with the untreated samples (Fig. 6, lanes 1-6). A slight increase in the cleavage product of caspase-2 was also detected (Fig. 6, lanes 

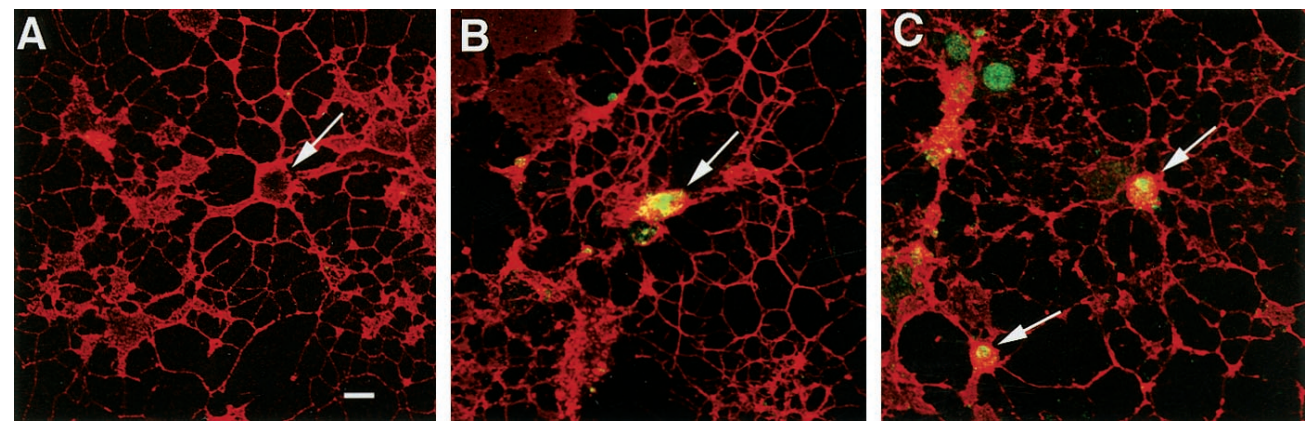

Figure 5. In situ immunodetection of activated caspase-3 (CPP32) in cultured oligodendrocytes. Confocal microscopy of oligodendrocyte cultures doublestained with the mature oligodendrocytespecific marker O1 (red) and the CM1 antibody (Srinivasan et al., 1998b), specific for the p18 subunit of the activated caspase-3 (green). The activated form of caspase- 3 was not observed in untreated culture $(A)$. Activated caspases can be seen in the cell body of O1-positive cells after $4(B)$ and $8(C)$ hr of NGF treatment. Arrows indicate cell bodies. Scale bar: $A-C, 10 \mu \mathrm{m}$.

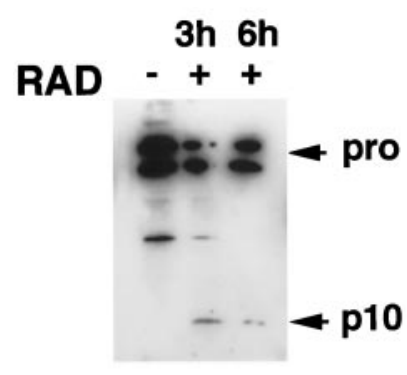

123

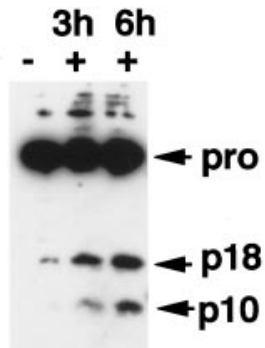

$\begin{array}{lll}4 & 5 & 6\end{array}$

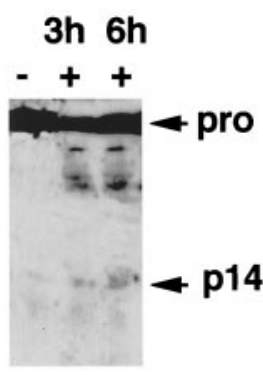

\begin{tabular}{lll}
7 & 8 & 9 \\
\hline
\end{tabular}

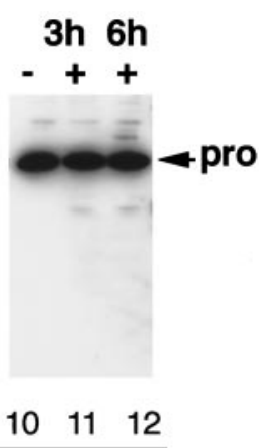

Caspase-8

Figure 6. A similar subset of caspases is activated after radiation damage. Oligodendrocyte cultures grown for $7 \mathrm{~d}$ were subjected to $\gamma$ irradiation at 100 rads for $32 \mathrm{~min}$. Total cell lysates were prepared from untreated cultures (lanes $1,4,7,10)$ or irradiated cultures harvested either 3 (lanes $2,5,8,11$ ) or 6 (lanes 3, 6, 9, 12) hr after treatment. Western blot analysis was performed using anti-caspase-1 antibody ICEp10(M20) (lanes 1-3), anti-caspase-3 antibody CSP-3 (lanes 4-6), anti-caspase-2 antibody Nedd-2p12 (lanes 7-9), and anticaspase- 8 polyclonal antibody CSP-8 (lanes 10-12). The procaspases forms, as well as their processed forms, are indicated.

7-9). In contrast, cleavage of caspase- 8 was not observed after radiation. These results indicate that caspase- $1,-2$, and -3 , but not caspase-8, are involved in radiation-induced oligodendrocyte death. $\gamma$ Radiation therefore preferentially activates the same subset of caspases in oligodendrocytes as NGF under these culture conditions.

\section{DISCUSSION}

In the present study, we demonstrate that specific caspases are activated after NGF-induced cell death of mature oligodendrocytes in culture. During differentiation of cortical oligodendrocytes, p75 expression is upregulated to high levels, and neutralizing antibodies against this receptor can block NGF-induced apoptosis (Casaccia-Bonnefil et al., 1996b). A variety of different caspase proforms are expressed in mature oligodendrocytes, including caspases 1-3, caspase-8, caspase-9, and caspase-11 (our unpublished observations). Caspase- 1 is preferentially activated during NGF treatment, and caspase- 2 and -3 activities are also elevated. In contrast, caspase-8, although expressed, is not activated after NGF binding to the p75 receptor. These results also explain the difference in the degree of protection observed with different caspase inhibitors. DEVD, the inhibitor of the effector caspase-3, shows complete inhibition, whereas YVAD, the inhibitor of the initiator caspase-1, shows more variability in protection against cell death. These results imply that besides caspase-1, there are other initiator caspases, such as caspase-2, that are involved in the apoptotic event and are not inhibited by YVAD.

Recruitment of caspase- 8 or Flice/Mach is required for TNF and Fas cytotoxicity. Whether caspase- 8 is directly recruited to the TNF receptor in oligodendrocytes is unknown; however, recruitment of caspase- 8 to the death domains of the p55 TNF receptor and Fas via adaptor proteins, such as FADD and TRADD (TNF receptor associated death domain), is critical for the initiation of apoptosis and activation of downstream caspases, such as caspase-3 (Nagata, 1997). A consensus death domain exists in the $\mathrm{C}$-terminal region of the $\mathrm{p} 75$ neurotrophin receptor; however, there are slight structural differences between p75 and Fas cytoplasmic domains (Liepinsh, 1997). Biochemically, the Fas death domain aggregates, whereas p75 does not self-associate in the same manner (our unpublished observations). These structural differences suggest that p75 may use alternative adaptor proteins, such as TNF receptor-associated factors (TRAFs), which may recruit signaling molecules involved in promoting cell death (Arch et al., 1998). A potential interaction of p75 with TRAF6 has been described recently (Khursigara et al., 1999).

The detection of $\mathrm{p} 75$ receptors in oligodendrocytes is observed under pathological or inflammatory conditions. We have detected p75 mRNA and protein in oligodendrocytes and in microglia and macrophages from multiple sclerosis plaques (Dowling et al., 1997). The enhanced expression of this receptor on oligodendroglial cells during inflammation could be responsible for greater sensitivity of these cells to apoptotic stimuli released at the site of injury. Of the caspase family members, only caspase- 1 has been shown both in vitro and in vivo to be involved in inflammatory processes (Fantuzzi and Dinarello, 1996; Li et al., 1997). Our data are consistent with this hypothesis that p75 signaling may play an active role in inflammation because NGF treatment of oligodendrocytes results in significant activation of caspase- 1 .

In contrast to rat postnatal oligodendrocytes, adult human oligodendrocytes do not appear to be susceptible to NGFmediated cell death in vitro (Ladiwala et al., 1998), although p75 was found to be expressed. One criteria for cell death is the activation of the c-jun kinase, which has been consistently observed downstream of NGF-dependent activation of p75 (Casaccia-Bonnefil et al., 1996b; Bamji et al., 1998; Yoon et al., 
1998). This response was observed in postnatal rat oligodendrocytes and not in adult human cells. These different responses emphasize the plastic nature of oligodendrocytes, which differ in responsiveness depending on the developmental stage and growth conditions of the cells. Also, it is clear that p75 expression alone is not sufficient to trigger the death program (Casaccia-Bonnefil et al., 1998). Introduction of high levels of p75 into oligodendrocyte precursor cells or in stem cells in the subventricular zone (Yoon et al., 1996) does not lead to an apoptotic outcome.

Nevertheless, growing evidence now supports a cell death function for p75 during neurotrophin responses. Although p75 levels have been shown to be necessary for optimal neuronal cell survival (Davies et al., 1993; Lee et al., 1994), expression of p75 leads to an increased rate of death in cell lines after serum withdrawal (Rabizadeh et al., 1993), in embryonic chick retinal cells (Frade et al., 1996), and in an NGF-dependent manner in cultured oligodendrocytes (Casaccia-Bonnefil et al., 1996b) and sensory neurons (Davey and Davies, 1998). Expression of the cytoplasmic domain of p75 in transgenic mice is sufficient to generate pronounced cell death in many neuronal populations (Majdan et al., 1997). Apoptosis mediated by NGF binding to p75 appears to take place in the absence of TrkA receptors, because coexpression of the appropriate cognate Trk receptor leads to inhibition of p75 death signaling (Yoon et al., 1998). An increase in the number of cholinergic neurons in the basal forebrain (Van der Zee et al., 1996; Yeo et al., 1997) and sympathetic neurons in the superior cervical ganglion (Bamji et al., 1998) of $\mathrm{p} 75^{-1-}$ mice lends support to the hypothesis that neurotrophins possess the ability to induce a cell death signal, as well as to provide trophic support.

The finding that $\mathrm{p} 75$-mediated cell death and $\gamma$ irradiation both activate caspase- 1 supports the hypothesis that this cysteine protease is primarily involved in events invoked during injury or inflammation (Hara et al., 1997). This would also imply that another important function of p75 is to participate during cytokine responses similar to those found for the other TNF cytokine receptor members. Further investigation into the regulation of p75 signaling will provide more insight into the mechanisms responsible for greater sensitivity to neurotrophins during development and after injury.

\section{REFERENCES}

Alnemri ES, Livingston DJ, Nicholson DW, Salvesen G, Thornberry NA, Wong WW, Yuan J (1996) Human ICE/CED-3 protease nomenclature. Cell 87:171.

Arch RH, Gedrich RW, Thompson CB (1998) Tumor necrosis factor receptor-associated factors (TRAFs) - a family of adaptor proteins that regulates life and death. Genes Dev 12:2821-2830.

Bamji SX, Majdan M, Pozniak CD, Belliveau DJ, Aloyz R Kohn R, Causing CG, Miller FD (1998) The p75 neurotrophin receptor mediates neuronal apoptosis and is essential for naturally occurring sympathetic neuron death. J Cell Biol 140:911-923.

Bansal R, Warrington AE, Gard AL, Ranscht B, Pfeiffer SE (1989) Multiple and novel specificities of monoclonal antibodies $\mathrm{O} 1, \mathrm{O} 4$ and $\mathrm{R}-\mathrm{mAb}$ used in the analysis of oligodendrocyte development. J. Neurosci Res 24:548-557.

Barker PA (1998) p75NTR: a study in contrasts. Cell Death Differ 5:346-356.

Barres BA, Hart IK, Coles HSR, Burne JF, Voyvodic JT Richardson WD, Raff MC (1992) Cell death and control of cell survival in the oligodendrocyte lineage. Cell 70:31-46.

Barrett GL, Bartlett PF (1994) The p75 receptor mediates survival or death depending on the stage of sensory neuron development. Proc Natl Acad Sci USA 91:6501-6505.

Bhat RV, DiRocco R, Marcy VR, Flood DG, Zhu Y, Dobranski P, Siman
R, Scott R, Contreras PC, Miller M (1996) Increased expression of IL-1 $\beta$ converting enzyme in hippocampus after ischemia: selective localization in microglia. J Neurosci 16:4146-4154.

Bredesen DE, Ye X, Tasinato A, Sperandio S, Assa-Munt N, Rabizadeh S (1998) p75NTR and the concept of cellular dependence: seeing how the other half die. Cell Death Differ 5:365-371.

Carter BD, Lewin GR (1997) Neurotrophins live or let die: does p75 NTR decide? Neuron 18:187-190.

Casaccia-Bonnefil P, Aibel L, Chao MV (1996a) Central glial and neuronal populations display differential sensitivity to ceramide-dependent cell death. J Neurosci Res 43:382-389.

Casaccia-Bonnefil P, Carter BD, Dobrowsky RT, Chao MV (1996b) Death of oligodendrocytes mediated by the interaction of nerve growth factor with its receptor p75. Nature 383:716-719.

Casaccia-Bonnefil P, Kong H, Chao MV (1998) Neurotrophins: the biological paradox of survival factors eliciting apoptosis. Cell Death Differ 5:357-364.

Cecconi F, Alvarez-Bolado G, Meyer BI, Roth KA, Gruss P (1998) Apaf1 (CED-4 homolog) regulates programmed cell death in mammalian development. Cell 94:727-737.

Davey F, Davies AM (1998) TrkB signalling inhibits p75-mediated apoptosis induced by nerve growth factor in embryonic proprioceptive neurons. Curr Biol 8:915-918.

Davies A, Lee K-F, Jaenisch R (1993) p75 deficient trigeminal sensory neurons have an altered response to NGF but not to other neurotrophins. Neuron 11:1-20.

Dechant G, Barde Y-A (1997) Signaling through the neurotrophin receptor p75 NTR . Curr Opin Neurobiol 7:413-418.

Dowling P, Raval S, Husar W, Casaccia-Bonnefil P, Chao M, Cook S, Blumberg B (1997) Expression of the p75 neurotrophin receptor in oligodendrocytes in multiple sclerosis. Neurology 48:A425.

Eldadah BA, Yakovlev AG, Faden AI (1997) The role of CED-3-related cysteine proteases in apoptosis of cerebellar granule cells. J Neurosci 17:6105-6113.

Ellis RE, Yuan JY, Horvitz HR (1991) Mechanisms and functions of cell death. Annu Rev Cell Biol 7:663-698.

Enari M, Talanian RV, Wong WW, Nagata S (1996) Sequential activation of ICE-like and CPP32-like proteases during FAs-mediated apoptosis. Nature 380:723-726.

Fantuzzi G, Dinarello CA (1996) The inflammatory response in interleukin-1b-deficient mice: comparison with other cytokine-related knockout mice. J Leukocyte Biol 59:489-492.

Frade JM, Barde Y-A (1998) Nerve growth factor: two receptors, multiple functions. BioEssays 20:137-145.

Frade JM, Rodriguez-Tebar A, Barde Y-A (1996) Induction of cell death by endogenous nerve growth factor through its $\mathrm{p} 75$ receptor. Nature 383:166-168.

Hakem R, Hakem A, Duncan GS, Henderson JT, Woo M, Soengas MS, Elia A, de la Pompa JL, Kagi D, Khoo W, Potter J, Yoshida R, Kaufman SA, Lowe SW, Penninger JM, Mak TW (1998) Differential requirement for caspase 9 in apoptotic pathways in vivo. Cell 94:339-352.

Hara H, Friedlander RM, Gagliardini V, Ayata C Fink K, Huang Z, Shimizu-Sasamata M, Yuan J, Moskowitz MA (1997) Inhibition of interleukin $1 \beta$ converting enzyme family proteases reduces ischemic and excitotoxic neuronal damage. Proc Natl Acad Sci USA 94:2007-2012.

Jacobson MD, Weil M, Raff MC (1997) Programmed cell death in animal development. Cell 88:347-54.

Khursigara, G, Orlinick, J, Chao MV (1999) Association of the p75 neurotrophin receptor with TRAF6. J Biol Chem 274:2597-2600.

Kuida K, Zheng TS, Na S, Kuan C, Yang D, Karasuyama H, Rakic P, Flavell RA (1996) Decreased apoptosis in the brain and premature lethality in CPP32-deficient mice. Nature 384:368-372.

Kuida K, Haydar TF, Kuan CY, Gu Y, Taya C, Karasuyama H, Su MS, Rakic P, Flavell RA (1998) Reduced apoptosis and cytochrome c-mediated caspase activation in mice lacking caspase 9. Cell 94:325-337.

Ladiwala U, LaChance C, Simoneau SJJ, Bhakar A, Barker, PA, Antel JP (1998) p75 neurotrophin receptor expression on adult human oligodendrocytes: signaling without cell death in response to NGF. J Neurosci 18:1297-1304.

Lee K-F, Davies A, Jaenisch R (1994) p75-deficient embryonic dorsal root sensory and neonatal sympathetic neurons display a decreased sensitivity to NGF. Development 120:1027-1033.

Li P, Allen H, Banerjee S, Franklin S, Herzog L, Johnston C, McDowell J, Paskind M, Rodman L, Salfeld J, Towne E, Tracey D, Wardell S, Wei 
F-Y, Wong W, Kamen R, Seshadri T (1995) Mice deficient in IL-1 $\beta$ converting enzyme are defective in production of mature IL- $1 \beta$ and resistant in endotoxic shock. Cell 80:401-411.

Li P, Allen H, Banerjee S, Seshardri T (1997) Characterization of mice deficient in interleukin-1 $\beta$ converting enzyme. J Cell Biochem 64:27-32.

Li Y-Q, Jay V, Wong CS (1996) Oligodendrocytes in the adult rat spinal cord undergo radiation-induced apoptosis. Cancer Res 56:5417-5422.

Liepinsh E, Ilag LL, Otting G, Ibanez CF (1997) NMR structure of the death domain of the p75 neurotrophin receptor. EMBO J 16:4999-5005.

Majdan M, Lachance C, Gloster A, Aloyz R, Zeindler C, Bamji S, Bhakar A, Belliveau D, Fawcett J, Miller FD, Barker PA (1997) Transgenic mice expressing the intracellular domain of the p75 neurotrophin receptor undergo neuronal apoptosis. J Neurosci 17:6988-6998.

McCarthy KD, de Vellis J (1980) Preparation of separate astroglial and oligodendroglial cell cultures from rat cerebral tissue. J Cell Biol 85:890-902.

Milligan CE, Prevette D, Yaginuma H, Homma S, Cardwell C, Fritz LC, Tomaselli KJ, Oppenheim RW, Schwartz LM (1995) Peptide inhibitors of the ICE protease family arrest programmed cell death of motorneurons in vivo and in vitro. Neuron 15:385-393.

Mirsky R, Winter J, Abney ER, Pruss RM, Gavrilovic J, Raff MC (1980) Myelin-specific proteins and glycolipids in rat Schwann cells and oligodendrocytes in culture. J Cell Biol 84:483-494.

Nagata S (1997) Apoptosis from death factor. Cell 85:355-365.

Namura S, Zhu J, Fink K, Endres M, Srinivasan A, Tomaselli KJ, Yuan J, Moskowitz MA (1998) Activation and cleavage of caspase-3 in apoptosis induced by experimental cerebral ischemia. J Neurosci 18:3659-3668.

Nicholson DW (1996) ICE/CED3-like proteases as therapeutic targets for the control of inappropriate apoptosis. Nat Biotechnol 14:297-301.

Rabizadeh S, Oh J, Zhong LT, Yang J, Bitler CM, Butcher LL, Bredesen DE (1993) Induction of apoptosis by the low-affinity NGF receptor. Science 261:345-348.

Schulz JB, Weller M, Klockgether T (1996) Potassium deprivationinduced apoptosis of cerebellar granule neurons: a sequential requirement for new mRNA and protein synthesis, ICE protease activity, and reactive oxygen species. J Neurosci 16:4696-4706.

Selmaj KW, Raine CS (1988) Tumor necrosis factor mediates myelin and oligodendrocyte damage in vitro. Ann Neurol 23:339-346.
Shimizu S, Eguchi Y, Kamiike W, Matsuda H, Tsujimoto Y (1996) Bcl-2 expression prevents activation of the ICE protease cascade. Oncogene 12:2251-2257.

Srinivasan A, Foster LM, Testa MP, Ord T, Keane RW, Bredesen DE, Kayalar C (1996) Bcl-2 expression in neural cells blocks activation of ICE/CED-3 family proteases during apoptosis. J Neurosci 16: $5654-5660$.

Srinivasan A, Li F, Wong A, Kodandapani L, Smidt Jr R, Krebs JF, Fritz LC, Wu JC, Tomaselli KJ (1998a) Bcl-xL functions downstream of caspase- 8 to inhibit Fas- and tumor necrosis factor receptor 1-induced apoptosis of MCF7 breast carcinoma cells. J Biol Chem 273:4523-4529.

Srinivasan A, Roth KA, Sayers RO, Shindler KS, Wong AM, Fritz LC, Tomaselli KJ (1998b) In situ immunodetection of activated caspase-3 in apoptotic neurons in the developing nervous system. Cell Death Differ 5:1004-1016.

Stoffel W, Bosio A (1997) Myelin glycolipids and their functions. Curr Opin Neurobiol 7:654-661.

Thornberry NA, Lazebnik Y (1998) Caspases: enemies within. Science 281:1309-1312.

Troy CM, Stefanis L, Greene LA, Shelanski M (1997) Nedd2 is required for apoptosis after trophic factor withdrawal, but not superoxide dismutase (SOD1) downregulation, in sympathetic neurons and PC12 cells. J Neurosci 17:1911-1918.

Van der Zee CEEM, Ross GM, Riopelle RJ, Hagg T (1996) Survival of

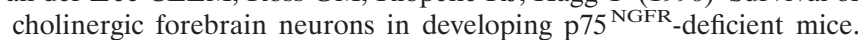
Science 274:1729-1732.

Yeo TT, Chua-Couzens J, Butcher LL, Bredesen DE, Cooper JD, Valletta JS, Mobley WC, Longo FM (1997) Absence of p75 ${ }^{\text {NTR }}$ causes increased basal forebrain cholinergic neuron size, choline acetyltransferase activity, and target innervation. J Neurosci 17:7594-7505.

Yoon SO, Lois C, Alvirez M, Alvarez-Buylla A, Falck-Pedersen E, Chao MV (1996) Adenovirus-mediated gene delivery into neuronal precursors of the adult mouse brain. Proc Natl Acad Sci USA 93:11974-11979.

Yoon SO, Carter BD, Casaccia-Bonnefil P, Chao MV (1998) Competitive signaling between TrkA and p75 nerve growth factor receptors determines cell survival. J Neurosci 18:3273-3281.

Yuan J, Shaham S, Ledoux S, Ellis HM, Horvitz HR (1993) The $C$. elegans cell death gene ced-3 encodes a protein similar to mammalian interleukin-1 $\beta$-converting enzyme. Cell 75:641-652. 